\title{
Sundials for Urban Farming in an Early Inca City
}

\author{
Uwe Christian Plachetka
}

University of Natural Resources and Life Sciences (BOKU), Vienna, Austria

*Corresponding Author: uwe.plachetka@gmail.com

Copyright $(2014$ Horizon Research Publishing All rights reserved.

\begin{abstract}
Information systems are essential for "response agriculture". The famous IntiWatanas, the Inca sundials were a technological detail of "response agriculture" as the development of the Inca Empire was a matter of coping with the challenges of the Medieval Climatic Anomaly in the Central Andean Highlands. Such archaic but smart techniques can be understood only when considered in their original socio-ecologic context.
\end{abstract}

Keywords Urban Farming, Inca, Sundial, Ecologic Management

\section{Introduction}

The IntiWatana is an Inca horizontal sundial made of a gnomon in the center of a round plate; reported to indicate the solstices and equinox (Bauer, Stanish 2003:65) IntiWatanas survived in the Inca cities of Machu Pichu and Pisaq situated above the mountain slopes terraced for urban agriculture. The IntiWatanain Pisaq is surrounded by small huts for its personnel above a pond to control the water inflow into surrounding terraced mountain slopes. Urban agriculture in Pisaq was based on local crop adaptation by controlled microclimatic heterogeneity (Hurtado Fuertes 2000:111-113). Inca instruments had a key function for "response agriculture". Today "Response agriculture" means farmers' ability to cope with the challenges of global warming. African traditional farmers use natural indicators for making decisions by different rationale than modern scientists do (Zuma-Netshiukhwi et.al. 2013). The problem is the communication of scientific knowledge to farmers in a way that makes sense to them. Therefore indigenous information systems should be studied and reconstructed. Even in modern times traditional farmers cannot simply download computer-generated agro-meteorological data to make use of them; however their traditional knowledge systems or cultures are of supreme importance for the future of our staple food: The Andean highland belongs to eight to ten agricultural areas of original crop evolution and diversity, known as Vavilov centers (Harlan 1970). These crop diversity hotspots are run by traditional farmers according to their traditional knowledge. Unlike modern farming the methods of these indigenous farmers promote an increase in crop diversity to avoid adverse effects of inbreeding (Brush 2004). The Andean highlands and their traditional farmers harbor the genetic reserves for potatoes (solanum tuberosum spp.), Quinoa (Chenopodia quinoa) and a wide range of other nutritive crops. Consequently the intervention of the last pre-European government of Peru, that of the Incas in agricultural systems and food production is palpable, which does matter for a proper understanding of diversity-promoting agricultural systems and response agriculture because the Incas had to face the challenges of the Medieval Climatic Anomaly(MCA) (Haberle S.G., Chepstow-Lusty 2000, Bauer 2004, Sublette Mosblech et.al. 2012). Their response was restoration ecology (Chepstow-Lusty, Johnson 2000). How did the Incas do so?

In contrast to their sophisticated crop laboratories the use of their simple but smart sundials and other instruments was comprehensible enough that $16^{\text {th }}$ century Spanish conquistadores could give comprehensible and adequate reports on the use of astronomical instruments for planning the terraced fields for urban agriculture in Inca cities. They are part of an information system (Beynon Davis 2007) whose reconstruction may contribute to a solution of the communication problem modern agro-meteorologists are faced when trying to endorse "response agriculture" (Stitger et.al. 2013).

\section{Material and Methodology}

My own survey study (Plachetka 2011) was devoted to find the roots of the development of the specific Inca system of ecologic management as documented by John Earls (1989, 2006).A historical document on the development of the agricultural calendar in the Andean highlands (Anonimo [1570] 1906) motivated the review of historical reports to find information on the use of astronomical instruments for city planning along with publications of anthropological archaeology (inter alia Rostworowski 1999, D’Altroy 2002, Bauer 2004, Bauer, Covey 2002, Erikson 1999; Stanish 2003). The anthropological models proposed in the specific literature were reviewed by publications on Andean agriculture (inter alia Tapia 1996, Hurtado Fuertes 2002) with the idea that 
Andean traditional and pre-Hispanic agriculture had to feed the personnel who realized this or that form of social development anthropologists and archaeologists are proposing. The findings of survey studies including field trips done in 2005 and 2006 are published (Plachetka, Pietsch 2009, Plachetka, Muñoz 2009, Plachetka 2011).Earls (2006:14-15) encouraged the Peruvian sociologist Muñoz (2009) to study modern forms of information-based regional development in Austia, Central Europe as realized in Kirchbach as Peruvian counterpart to our studies on that of the Incas.

As Tipón is portrayed as an pre-imperial Inca constructed before the rule of Pachacutek (Bauer, Covey 2002) i.e. before the introduction of regional calendars adapted to regional vegetation periods (Anonimo [1570] 1906) checking the orientation of its agricultural terraces according to the solar azimuths of the vegetation period is not too complicated: The agricultural calendar of Guaman Poma ([1615] 1987) is the earliest survived version of the Andean agricultural calendar indicating the months and the related agricultural activities. The next step was to get to Tipón: It was the palace of the retired Inca Yahuar Huacac (Bauer, Covey 2002), this means, it operated before the full operation of Moray. The Inca palace Tipón is situated at $13^{\circ}$ $33^{\prime} 32^{\prime \prime} \mathrm{S}$ and $71^{\circ} 47^{\prime \prime} 12^{\prime \prime} \mathrm{W}$. at 3574 m.a.s.l. It is a lesser known touristic site of Peru. Some negotiations at one of the small travel agencies at Cusco's main place ("plaza de armas") got me a car and a student of archaeology as driver to make a trip to Tipón. There I measured the compass orientation of the terraced ravine in Tipon using a directional compass and a Swiss army compass embedded in a ruler for the exact orientation of the suspending walls of the terraced fields. These orientations were compared to the simulated solar azimuths of sunrise and sunset at the equinoctial dates and the solstices at Tipón. The simulation was done by the astronomical computer software Guide 8.0. These lines are drawn using vintage geometrical instruments: Rulers and a pair of compasses to make the azimuths visible on the field sketch of Tipón.

\section{Results}

The following long table (Table 1) gives the agricultural calendar as conserved by Guaman Poma in an explicit form. The abbreviation W.P stands for Waman Puma (classic Spanish has no $\mathrm{W}$ and uses $\mathrm{g}$ in now unlikely places such as in inga instead of Inka or Inca), the number is the original folio, the number in [brackets] indicates the corrected pagination by the editors.

Table 1. The agricultural calendar by Guaman Poma in explicit form (Waman Puma) (before 1615)

\begin{tabular}{|c|c|}
\hline Reference and Month & Activities reported by Guaman Poma \\
\hline $\begin{array}{l}1131 \text { [1141] January: } \\
\text { Capac Raymi and } \\
\text { camayquilla (fallow } \\
\text { month) }\end{array}$ & $\begin{array}{l}\text { Heavy rain falls, so that young maize and potatoes are eaten. The people are spinning and } \\
\text { weaving collectively. There is a shortage of food supply, because the seed period is finished. }\end{array}$ \\
\hline $\begin{array}{l}1134 \text { [1144] February: } \\
\text { Paucar Varay, } \\
\text { hatunpucuyquilla (Month } \\
\text { of maduration) } \\
\text { to } 1135 \text { [1145] }\end{array}$ & $\begin{array}{l}\text { Digging and "plowing" with the chaquitaccla (in historical texts: taccla) the Andean spade. Maize } \\
\text { or ... potatoes are sown. The peasants say chacmacuyqilla to this month. From this month until } \\
\text { march fruits from the plains are transported; peasants have to guard the imperial storehouses } \\
\text { (Qollca). During this month the rivers have much water. Potatoes are planted for the village } \\
\text { community, the church and the poor people. The irrigation channels have to be cleaned, as well as } \\
\text { the streets and the manantiales. } \\
\text { ZarapTuta Caway Mitan is the typical activity. [The maize (zara) has to be watched during night]. }\end{array}$ \\
\hline $\begin{array}{l}\text { 1137[1147] March: Pacha } \\
\text { Pucuy Qilla - Month of the } \\
\text { world's maturing. } \\
\text { Folk name: } \\
\text { ChaupiPucuy quilla }\end{array}$ & $\begin{array}{l}\text { During this month the Inca ... sends officials to all the villages with the task to rationalize the } \\
\text { food. This was a necessity to avoid the native's consuming all the food so that they would have } \\
\text { nothing to eat and starve by famine later on. The peasants call this month Chaupi Pucuyquilla - } \\
\text { half matured month. In this month there is enough food ... }\end{array}$ \\
\hline $\begin{array}{l}1140[1150] \text { April: Inca } \\
\text { Raimi, camay quilla } \\
\text { Folk name: } \\
\text { zara caruay }\end{array}$ & $\begin{array}{l}\text { This month is called zaracaruay, maturing of the maize (zara = maize) or zizayquilla (month of } \\
\text { flowers). In the lowlands, the plains the wine is cheap and the food is expensive at this month, } \\
\text { whereas in the highlands the food is cheap. Anyway theft is a severe problem. }\end{array}$ \\
\hline $\begin{array}{l}1143 \text { [1153] May: } \\
\text { HatunCusqui, Amoray } \\
\text { quilla, } \\
\text { Folk culture: } \\
\text { calchay, zara arcuy, zara } \\
\text { tipi, zara muchay quilla. }\end{array}$ & $\begin{array}{l}\text { This is the month of maize harvest and to pick the grains - e.g. for brewing beer (chicha). The } \\
\text { selection process was: (i)allinzara: good maize i.e. maize of good quality, (ii) muhozara: Seed } \\
\text { maize, (iii) chusuzara: empty maize, (iv)hutozara small maize. } \\
\text { Each one of these now categorized mais grains has its specific chulluna (barrel), chauay } \\
\text { (storehouse) and collca (deposit). } \\
\text { During May flowers are cooked for paintings, and cloth is woven for the sapsi, the communal } \\
\text { deposit. ... }\end{array}$ \\
\hline $\begin{array}{l}1146 \text { [1156] June: Haucay } \\
\text { Cusqui Quilla } \\
\text { popular : Chuño } \\
\text { morayazaroyqilla. }\end{array}$ & $\begin{array}{l}\text { The potato month: Potatoes are sown, as well as oca, ullucu, and chuno is prepared as well as } \\
\text { cocoba (unknown), tamos, and other forms of dehydrated and therefore preserved potato powder, } \\
\text { especially moraya. } \\
\text { This preserved potato powder is the staple food for all the year, together with oca, ullucu, mashua } \\
\text { (mashwa) and quinua. These products of potatoes are used to feed the workers for the minga } \\
\text { (collective labor). } \\
\text { These fruits or the potato powder is stored in piuras and cullunas (barrels). }\end{array}$ \\
\hline
\end{tabular}




\begin{tabular}{|l|l|}
\hline $\begin{array}{l}1149 \text { [1159] July: } \\
\text { Chacraconacuyquilla. } \\
\text { Popular: Amorayquilla } \\
\text { (month of harvest). }\end{array}$ & $\begin{array}{l}\text { In this month all the preserved harvest and dry vegetables are put into the deposits such as yuyo } \\
\text { (an aquatic plant that can be eaten)... [Livestock is] supplying the natural fertilizer, carried to the } \\
\text { fields. The wells (pozos) and "cochas" (artificial lakes) are cleaned to start the irrigation for the } \\
\text { michicazara (early maize) and little potatoes (chaucha papa) or early potatoes (mauay papa). And } \\
\text { the land will be redistributed. }\end{array}$ \\
\hline $\begin{array}{l}1152 \text { [1162] August: } \\
\text { Chacra [T]apuy Quilla : } \\
\text { month of land opening }\end{array}$ & $\begin{array}{l}\text { This is the month of sowing early maize and early potatoes of the chaucha papa variety. Sowing } \\
\text { period is from the day of Santiago Mayor (July 25 according to Guaman Poma's calendar), in } \\
\text { Cusco sowing started earlier than the day of Santiago in July.... The preparation of the chacras } \\
\text { happens with a ritual and songs of victory ... }\end{array}$ \\
\hline $\begin{array}{l}1155[1165] \text { September: } \\
\text { Coya Raymi quilla } \\
\text { popular: zara tarpuy quilla }\end{array}$ & $\begin{array}{l}\text { This is the month of seed for maize and early potatoes ... because the wind comes from the sea } \\
\text { in the north [says Guaman Poma]. } \\
\text { Again, famine is mentioned but in the context of the clergical presence in Peru - }\end{array}$ \\
\hline $\begin{array}{l}1158[1168] \text { Octobre: Oma } \\
\text { Raymi Quilla }\end{array}$ & $\begin{array}{l}\text { The birds have to be expelled from the seeds. During the Inca times, public meals were } \\
\text { prepared. ... }\end{array}$ \\
\hline $\begin{array}{l}1161 \text { [1171] November: } \\
\text { Aiamarcai Quilla; popular: } \\
\text { yacuuanayquilla, month of } \\
\text { water shortage. }\end{array}$ & $\begin{array}{l}\text { During Inca times this was the month of the passed by people [?] as a matter of fact, the fields } \\
\text { have to get irrigated (chacracarpay). Vegetables are sown during this month [it's Summer in Peru, } \\
\text { but Summer is the rainy period]. }\end{array}$ \\
\hline $\begin{array}{l}1164[1174] \text { December: } \\
\text { CapacIntiRaymiQuilla }\end{array}$ & Rainfall begins and one has to seed papas, ocas, quinua, wheat and maiz. \\
\hline
\end{tabular}

The following table gives the calculated azimuths by the astronomical software Guide 8.0

Table 2. Solar azimuths Tipon $13^{\circ} 33^{\prime} 32^{\prime \prime}$ South, $71^{\circ} 47^{\prime} 12^{\prime \prime}$ West, 3574 m.a.s.1. - 1300 to 1400 C.E

\begin{tabular}{|c|c|c|c|c|c|c|}
\hline \multirow[t]{2}{*}{ Date } & \multicolumn{3}{|c|}{ Equinox azimuths } & \multicolumn{3}{|c|}{ Solstice Azimuths } \\
\hline & Date in Julian cal. right & Sunrise & Sunset & Date & Sunrise & Sunset \\
\hline \multicolumn{7}{|c|}{ AD 1300} \\
\hline Jul. & 12.03 & 90.8 & 269.5 & 13.06. & 66.4 & 293.6 \\
\hline Greg. & 20.03 & & & 21.06 & & \\
\hline Jul. & 15.09. & 90.7 & 269.1 & 13.12. & 115 & 245 \\
\hline Greg. & 23.09 & & & 21.12 & & \\
\hline \multicolumn{7}{|c|}{ AD 1350} \\
\hline Jul. & 12.03 & 90.8 & 269.4 & 14.06. & 66.5 & 293.6 \\
\hline Greg. & 20.03 & & & & & \\
\hline Jul. & 15.09 & 90.7 & 269.1 & 13.12 & 115 & 245 \\
\hline Greg. & 23.09 . & & & 21.12 & & \\
\hline \multicolumn{7}{|c|}{ AD 1400} \\
\hline Jul. & 11.03. & 90.9 & 296.4 & 13.06. & 66.5 & 293.6 \\
\hline Greg. & 20,03 & & & 22.06 & & \\
\hline Jul. & 14.09 & 90.7 & 269.2 & 12.12 & 115 & 245 \\
\hline Greg. & 23.09 & & & 21.12 & & \\
\hline
\end{tabular}

Source: Guide 8.0

As a synthesis the sketches for the orientation of the city of Tipon towards the vegetation period is given by the geometrical Figure1: 


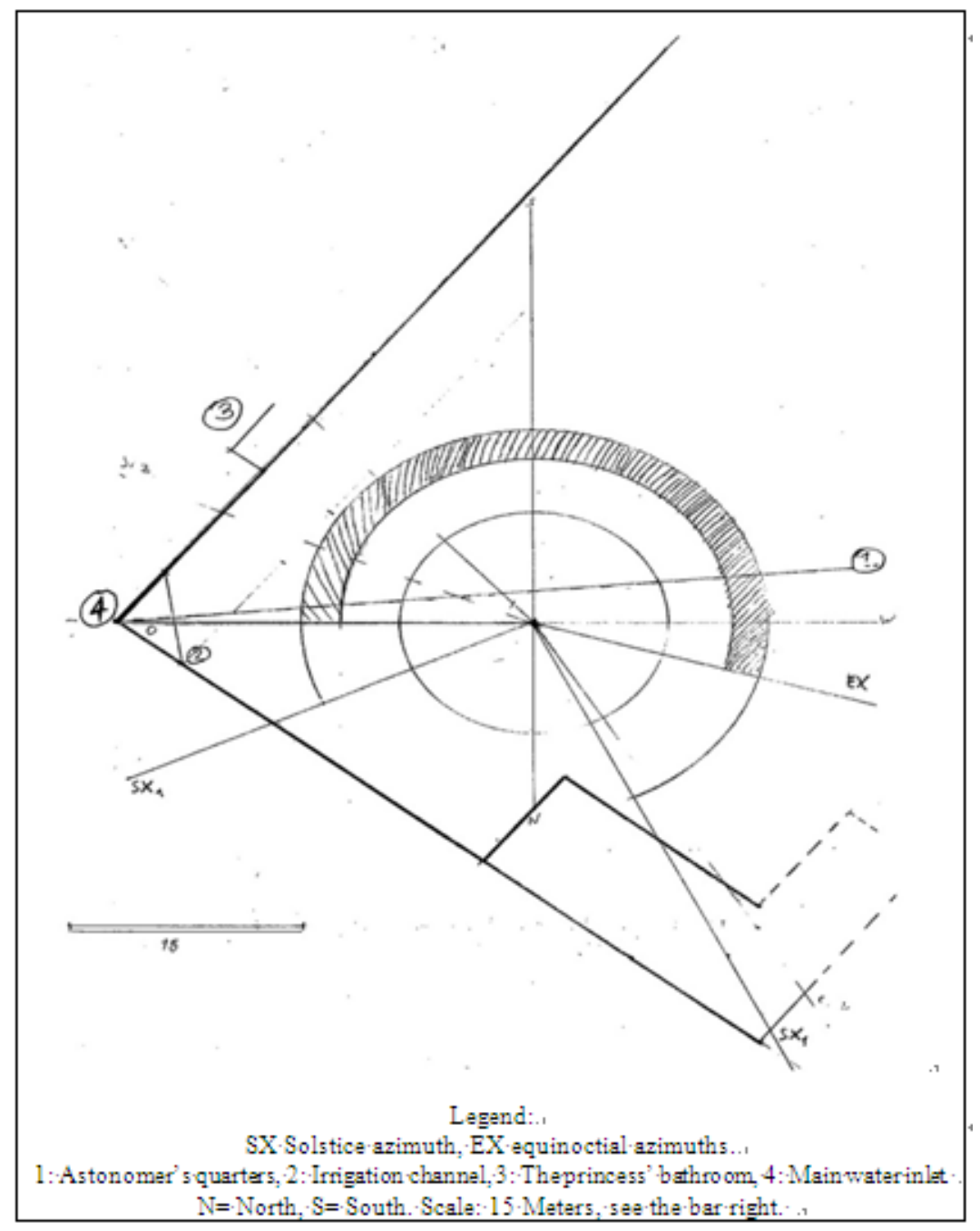

Figure 1. The astronomical orientation of Tipón

The astronomy done in Tipón corresponds to Sarmiento de Gamboa's report on the agricultural terraces in Cusco (Sarmiento 1572, chapter 30). Sarmiento describes the Inca's astrolabe (a kind of sextant) and its use for planning agricultural terraces. The famous "IntiWatana" is mentioned by Sarmiento as "relojanual" in the Spanish original text, which means "a year's clock". It was constructed (calibrated?) after the data were taken by the "astrolabe". This "astrolabes" was formed by two staffs with holes on top acting as visors. The sun rays' "focus" as produced by these hole-lenses were drawn into the sand for planning purposes. The IntiWatana served for organizing the agricultural activities on the terraces. The original name of the IntiWatana as introduced by Inca Yupanqui Pachacutek is Pacha Unan Chac (Betanzos ([1551]1999:17) Book I, Chapter 15), which may be a corrupt form for pachaunanchacrayuq. Pasted on a compass rose the geometrical figure to represent the use of this pachaunanchacrayuq (literarely: field time) is perhaps more comprehensible (Figure 2): 


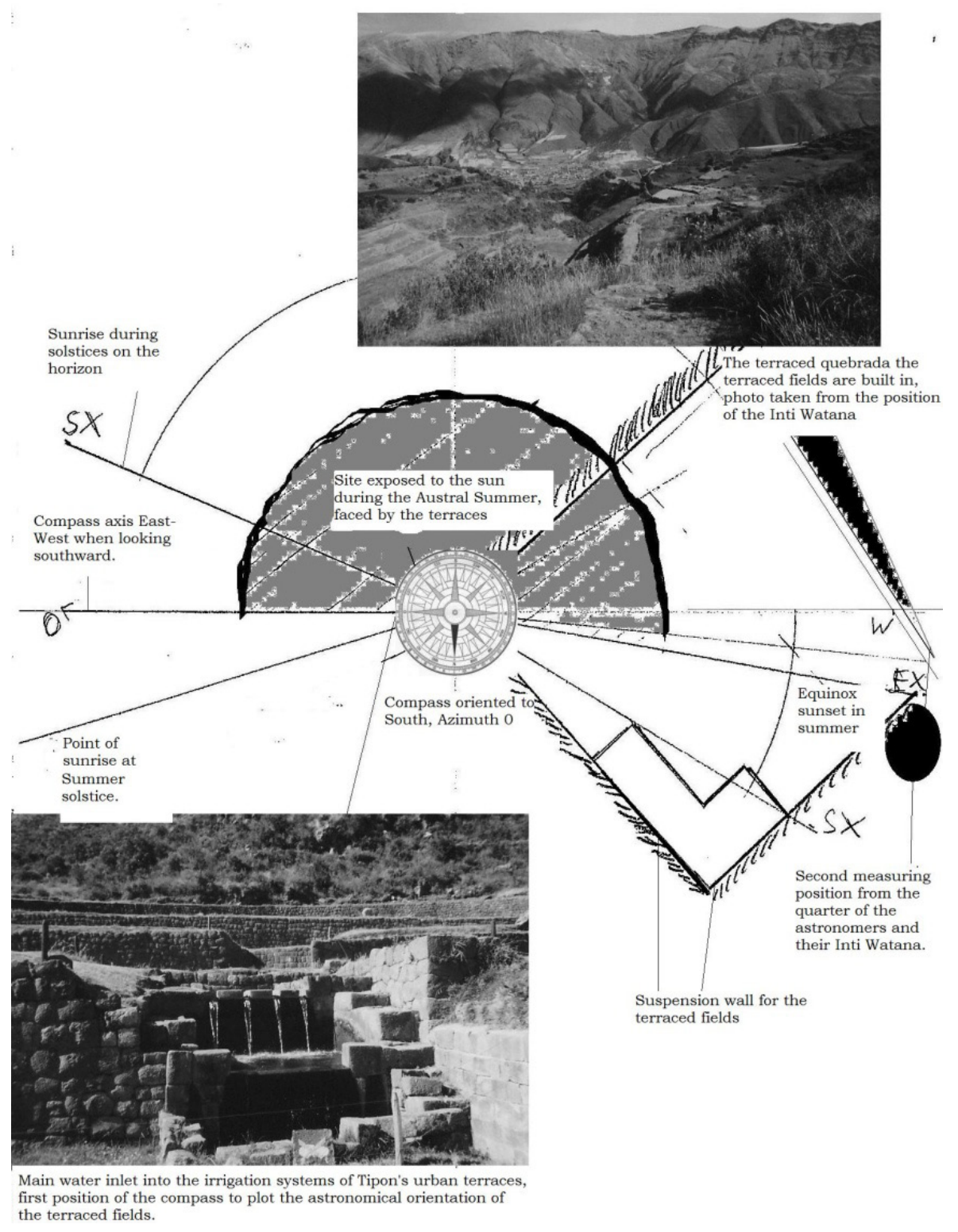

Figure 2. An illustrated draft (no scale) of Tipon with photos. The terraced fields (barb lines) are facing the lines of sunrise and sunset during the solstices (SX) and equinoxes (EX), photos are taken by the author (Plachetka 2011:170)

The orientation towards the solar azimuth during the vegetation period is made visible. The next step is to put these results into the (i) climatological and (ii) geographical context of the development of the Inca Empire as elaborated by literature review: The (i) Late Intermediate period in Andean prehistory (900 AD to $1400 \mathrm{AD}$ ) was coincidental with the MCA. The foregone empires, the Wari and Tiwanaku, ceased to exist by $900 \mathrm{AD}$ at the onset of the MCA; inter alia due to a general fragility of the South Andean landscape, alterations in the patterns of atmospheric circulations (Mächtle, Eitel 2013) and problems with intensive potato agriculture (Bandy 2004). The "Late Intermediate" is climatologically coincidental to the Medieval Climatic Anomaly (900-1350 AD). The Inca changed to maize. A provincial competence center for maize agriculture explicitly mentioned in a historical document was used for foreign policy by "maize diplomacy"
(El Alcaya 1906) but it is Samaipata $\left(19^{\circ} 10^{\prime} \mathrm{S}, 43^{\circ} 49^{\prime} \mathrm{W}\right.$, 1900 m.a.s.l.) at the Andean frontier in Bolivia.

The (ii) geographical factors to enforce the development of diversity-promoting agricultural systems are chiefly weather-related risks due to the fact that the Innertropical Convection Zone (ITCZ) draws the trade wind as rain suppliers from the Atlantic Ocean, whereas Pacific moist is redirected to South East Asia. In terms of agricultural engineering the Andean mountain range consists of the green Andes in what is now Columbia, Venezuela and parts of Ecuador, where rain-fed agriculture is no problem. The yellow Andes, in what is now Central and Southern Peru down to the ancient Inca capital Cusco $\left(13^{\circ}, 31^{\prime} 27^{\prime}\right.$, S(outhern Latitude), 71 $58^{\prime} 24^{\prime \prime}$ W(estern) L(ongitude), 3425 m.a.s.l. (meters above sea level)) are characterized by an explicit rainy and dry period, so that artificial irrigation is used. The dry Andes begin approximately at the latitude 
of Sicuani $14^{\circ} 17^{\prime} 08^{\prime \prime} S, 71^{\circ} 13^{\prime} 20^{\prime \prime} \mathrm{W}, 3562$ m.a.s.l.), stretching along the mountain ranges of the Cordillera to the Lake Titicaca and beyond. They are risk prone, that means the minimum temperature and the rainfall for determining the vegetation periods is hardly predictable around the Lake Titicaca $\left(15^{\circ} 45^{\prime} \mathrm{S}, 69^{\circ} 41^{\prime} \mathrm{W}\right)$. Southward of it, precipitation decreases and gets zero at the Atacama Desert. The Chilean South Andes are of less interest for investigations on traditional agriculture(Tapia 1996). The document on the development of the Inca calendar (Anonimo [1570] 1906) explains that in the beginnings biological indicators were used, mentioning cañahua (Chenopodium pallidicaule)cultivated in the Altiplano. Afterwards an Inca introduced a calendar system which failed to cope with the diversity of the vegetation periods depending on the altitude in mountain areas. This simple calendar is associated to "Viracocha Inca" who had Tipon constructed. His successor Pachacuek Inca, was the founding father of the Inca Empire. He developed a calendar system that did so. His backbone for doing so is the already mentioned crop laboratory composed by terraced sinkholes at Moray $\left(13^{\circ}, 19^{\prime} 32^{\prime \prime}\right.$ S(outhern Latitude), $71^{\circ} 11^{\prime} 45^{\prime}$ ' W(esten Longitude) 3574 meters above sea level (m.a.s.l.)) situated in the heartland of the Empire.Earls measured soil temperatures etc. at the main sinkhole, Quechuq $(80 \mathrm{~m}$ deep $)$ plotting a considerable heterogeneity of microclimatic gradients: Several varieties of maize, packed into a small space raise the likelihood of emerging new varieties by cross pollination. The microclimatically specific slots in the terraced sinkhole acted as selectors. Varieties adapted to specific conditions survived. Earls (1976) argues that Inca Pachacutek develops a calendar system adapted to regional vegetation periods as Viracocha's pre-imperial calendar failed (Anonimo [1570] 1906). This narrative is coincidental with the pollen record in the Marcacocha lake sediment (Chepstow- Lusty et. al. 2009) indicating a pre-Inca peak in Maize pollen, but not accompanied by a peak in Alnus pollen, as it happened during the pre-imperial (there: Killke) phase and during the Imperial Inca phase: Alnus is an highland tree whose reforestation matters for infiltration forests to keep water sheds. Unfortunately these data were taken from the episodically filled Marcacocha lake (13'30's, $72^{\circ} 12^{\prime} \mathrm{W}$; 3355m.a.s.l.) eastward of Ollantaytampu $\left(13^{\circ} 15^{\prime} 24^{\prime}\right.$ 'S, $72^{\circ} 16^{\prime} 02^{\prime}$ ' W, 2879 m.a.s.l. (the upper part of the Inca City on the Northern hillslope)).

Tipón $\left(13^{\circ} 33^{\prime} 32^{\prime \prime} \mathrm{S}\right.$ and $71^{\circ} 47^{\prime \prime} 12^{\prime \prime} \mathrm{W}$. at 3574 m.a.s.l.)belonging to the pre-imperial realm of the Incas (Bauer, Covey 2002) is a palace with a sundial center similar to Pisaq. Tipon was constructed before Moray was in full operation.

\section{Discussion}

Earls (1989, 2006) proposed Inca model of environmental control is now endorsedby positive correlation rates of biodiversity and human population centers (Fjeldså 2007). In terms of environmental history, the Inca Empire rose after the end of the Medieval Climatic Anomaly (MCA): The MCA means a La Niña like Pacific Ocean (Graham et.al. 2011). During the MCA the American Inner-Tropical Convection zone (ITCZ) shifted so that the moisture transport of the trade winds benefitted the Cusco region, disadvantaging the Altiplano (Mächtle, Eitel 2013), explaining the proxy data provided by Erickson (1999) which leaves another enigma: How to conclude that the typical Altiplano raised fields (Camellones) were not abandoned in the course of the end of the Tiwanaku Empire (Stanish 2003): If Bandy (2004) is right, intensive potato agriculture on raised fields during the Tiwanaku (Bandy 2004) produced a potato crisis: The Andean region is the potato's Vavilov center, which means it is also the place of the evolution of crop specific parasites. Introducing maize as the Inca Empire's staple by proto-scientific agriculture means a new source of imperial soft power. The present paper is not a forum to discuss Moray (Wright et.al. 2011) in the absence of accessible data generated by modern instruments due to the fact that a possible hydrological interpretation of Moray matches other results of the survey study (Plachetka 2011): Tipon as a "pre-Moray Inca palace" is a milestone for Inca development of water management technologies (Wright 2006). It displays essential features of the standard model of an Inca city, but water harvest for maize cultivation during drought was done also by the carved rocks, e.g. that of Samaipata, belonging to Albert Meyers pre-Imperial displaced "Inca X" (Meyers 2002) whose carved rocks can be used for rain harvesting (Plachetka, Pietsch 2009).

Tipón's place of observation is overlooking the maize terraces, situated in a terraced ravine with no changing patterns of vegetation, so it could have been constructed to take the utmost out of the solar power during the vegetation period by using the IntiWatana as a bearing plate. This practical "agricultural astronomy" was possibly less sophisticated than Reiner Tom Zuidema's reconstructions, whose touch-stone is the system of the so-called cheques. These are a kind of (reported)geomantic lines radiating out of the Cusco's chief temple, the temple of the sun. Kerstin Nowack (1998) ventured an assessment of Zuidema's work: It is hard to confirm some of his assumption by means of professional astronomy.

\section{Conclusion}

"Decline and re-launch" stories of archaic Empires matter to socio-ecologic resilience research (Terwiliger et.al. 2013): D'Altroy (1992) presented figures proving that the Incas could not perform bulk transportation which is required to match standard anthropological models of the Inca state as a "redistributive state" (Beyers 2001): The "knowledge society", whose backbone is an adequate information system for end-users. The famous Inca mail runners (Chasquis) and their knotted strings (Quipus) 
served for the transmission of information, but an information system implies that incoming sets of information are comprehensible, allowing action (Beynon Davies 2007). The IntiWatana is a tangible reminder of the sophisticated way the Incas organized their urban agriculture, motivated by their intensified maize agriculture, but it is not an instrument for doing measurements for calendars but to communicate the results to the end-users. The Inca cities should not be considered as Old-world styled cities but as regional competence centers endorsing the conception of Earls (2006): Terraces for crop experimentation, sundials and terraces for agricultural production should be considered as nodes in an information network based on parallel data proceeding. This means that regional experimentation gardens for local farmers should act in a circuit allowing feedbacks and multiple calibrations of generated data and experimentation results - and the data should be transmitted in a comprehensible way. Exactly the same problem is relevant to modern response agriculture e.g. in Indonesia where agro-meteorologists are searching for information systems accessible by farmers (Stigter et.al. 2013).

\section{REFERENCES}

[1] Anonímo [1570?] (1906) "Discurso de la descendencia y gouierno de los Ingas" In: Victor M. Maúrtua (Ed.), Juicio de límites entre el Perú y Bolivia , Prueba peruana presentada al Gobierno de la República Argentina 8, pp. 149-165. Barcelona

[2] Bandy, Matthew S. (2004) "Energetic efficiency and political expediency in Titicaca Basin raised field agriculture" Journal of anthropological archaeology 24, pp. 271-296

[3] Beyers, C. (2001) Directions in the Ethnohistorical Research on Inca state and Economy, Toronto: York University

[4] Bauer, Br. (2004) Ancient Cusco. Heartland of the Inca, Austin: University of Texas Press

[5] Bauer, Br. S., Cowey, A.L. (2002) „Processes of state formation in the Inca Heartland (Cuzco, Peru) American Anthropologist 104(3), pp. 846-864

[6] Bauer, Br; Dearborn, D. S. (2003) Astronomía e Imperio en los Andes (Estudios y debates regionales Andinos 98) Cusco: Centro de Estudios Andinos Bartolomé de las Casas

[7] Betanzos, J. De (ed. C.M. Rubio) (1999) Suma y narración de los Incas (Ediciónes Especiales UNSAAC Siglo XX, 1), Cusco: Universidad San Antonio Abad

[8] Beynon-Davies,P. (2007) "Informatics and the Incas" International Journal of Information Management 27 (2007):306-31

[9] Brush, S.B. (2004) Farmers' bounty: locating crop diversity in the contemporary world New Haven et.al. Yale University Press

[10] Chepstow Lusty A., Johnson P. (2000) "Inca Agroforestry:
Lessons from the past" AMBIO: A Journal of the Human Environment, 29(6):322-328. 2000

[11] Chepstow Lusty, Alex J.; Frogley M.R.; Bauer, Brian S.; et.al. (2009) "Putting the rise of the Inca Empire within a climatic and land management context" Climate of the Past 5,pp.375-388

[12] D'Altroy T. N. : Provincial Power in the Inca Empire, Washington D.C.: Smithonian institution

[13] D'Altroy, T.N. (2002) The Incas, Malden, Oxford, Victoria: Blackwell Publishing

[14] Earls, John (1976) „La evolución de la administración ecológica inca" Revista de Museo naciónal 42,pp.207-45,

[15] Earls J. (1989) Planificación Agricola Andina, Lima: COFIDE y Universidad Pacífico

[16] Earls, J. (2006) La agricultura andina ante una globalización en desplome, Lima: CISEPA and Pontíficia Universidad Católica del Perú

[17] Erikson, C.1. (1999) "Neo-environmental determinism and agrarian 'colapse' in Andean prehistory" Antiquity 73(281),pp. 634-642

[18] El Alcaya (1906) "Relación cierta..." in: Victor M. Maúrtua (Ed.), Juicio de limites entre el Perú y Bolivia , Prueba peruana presentada al Gobierno de la República Argentina 9, Moxos 1, pp. 124-136. Madrid

[19] Fjeldså, Jon (2007) "The relationship between biodiversity and population centres: the high Andes region as an example" Biodiversity and Conversation 16 (10) Sept. 2007

[20] Graham, N.E.; Ammann, C.M.; Fleitmann, D.; Cobb, K.M.; Luterbacher, J. (2011) "Support for Global Climate reorganization during the "Medieval Climate Anomaly" Climate Dynamics 37,pp.1217-1245

[21] Guaman Poma de Ayala, Felipe [1615] ed. J.V. Murra, R. Adorno, J. Uriotse: (1987) Nueva Crónica y buen gobierno (Crónicas de América 29) 3 Vols, Madrid:Historia 16,

[22] Guide 8.0: Documentation of Software: http://www.astronomyforum.net/astronomia-forum/64984-so ftware-guide-8-0-a.html(05/14/2010)

[23] Haberle, S.G., Chepstow-Lusty, A. (2000) „Can Climate influence Cultural Development? A View through time" Environment and History 6(3),pp.349-369

[24] Harlan, J.R. (1970) "Agricultural origins: Centers and Non-Centers", Science 174,pp. 468-474

[25] Hemming, J.(1970) Theconquest of the Incas, London

[26] Hurtado Fuertes, C. (2000) [in Spanish] La alimentación en el Tahuantinsuyo, Lima:Instituto de Cultura Alimentaria Andina

[27] Lieberman, V.(2003) Strange Parallels: Southeast Asia in Global Context c.800-1830, Cambridge, New York et. al.: Cambridge University Press

[28] Mächtle, B., Eitel, B. (2013) "Fragile landscapes, fragile civilizations - How climate determined societies in the pre-Columbian south Peruvian Andes" Catena 103,pp. 62-73

[29] Meyers, A. (2002) [in Spanish] "Los Incas - 
barbarousadvenicidos o herederos del Tiwanaku?" in El Hombre y los Andes. Homenaje al Franklin Pease G.Y., editedby J. Flores Espinoza y T. Varón Gabai, Vol 2, Lima, pp.525-563

[30] Munoz Villa, L. H. (2009) "Los diferentes usos de las TICS en zonas rurales: KirchbachAustria "Aldea Global Popular" y el anexo de Tinyari Chico, Chupaca-Perú"TikpaPachapaq 1(1), Huancayo-Peru pp.4-8

[31] Nowack, K. (1998) Ceques and more. A critical assessment of R. Tom Zuidema's Studies on the Inca (Bonner AmerikanistischeStudien 31), Bonn - MarktSchwaben (Germany).

[32] Plachetka U. Chr., Pietsch, St. A. (2009) "El Centro Vaviloviano en el Perú: Un conjunto socio-ecológico frente a riesgos extremos" TikpaPachapaq 1(1), Huancayo-Peru pp.9-16

[33] Plachetka, U. Chr., Munoz Villar, L.H. (2009) Peru - Cultura Vaviloviana? Un ejemplo para el "experimento histórico" según Jared Diamond” ,TikpaPachapaq1(1), Huancayo-Peru pp.18-21

[34] Plachetka, U. Chr. (2011) [in German] Die Inka, das Imperium, das aus der Kälte kam (Mensch und Gesellschaft 11), Frankfurt - New York: Peter-Lang

[35] Rostworowski de Diez Canseco, M. (1999) Historia del Tawantinsuyu ( $2^{\mathrm{a}}$ edición revisada y ampliada): Instituto de Estudios Peruanos y PromPeru.

[36] Sarmiento de Gamboa, P. [1572] (1907) History of the Inca Empire, translated by $\mathrm{Cl}$. Markham (Works Issued by the Hakluyt Society) Reprint: In Parenthesis Publications, Peruvian Series, Cambridge Ontario [Url]: http://www.yorku.ca/inpar/sarmiento_markham.pdf $(05 / 14 / 2012)$.
[37] Stanish, Ch. (2003): Ancient Titicaca. The evolution of a complex society,Berkely, Los Angeles, London: University of California Press

[38] Stigter, K., Winarto, Y. Ofori, E., Zuma-Netshiukhwi, G.,Nanja D, Walker, S. (2013) "Extension Agrometeorology as the Answer to Stakeholder Realites: Response farming and the Consequences of Climate Change" Athmosphere 4,pp.237-253

[39] Sublette Mosblech, Nicole A.; Chepstow-Lusty, Alex; Valencia, Bryan G.; Bush, Mark B. (2012) "Antropological control of late-Holocene landscapes in the Cuzco region, Peru" The Holocene 1-12 (accepted 9. March 2012).

[40] Tapia, M. N. (1996) [in Spanish]Ecodesarrollo en los Andes altos, [Lima]: Fundación Friedrich Ebert

[41] Terwiliger, V.J., Eshetu, Z., Disnar, J-R., Jacob, J., Adderley, W.P., Huang, Y., Alexandre M., Fogel, M.L. (2013) "Environmental change and the rise and fall of civilizations in the Northern Horn of Africa: An approach combining $\delta \mathrm{D}$ analyses of land-plant derived fatty acids with multiple proxies in soil" Geochimica et CosmochimicaActa 111 (2013), pp.140-161

[42] Wright, K (2006) Tipon: Engineering Masterpiece of the Inca Empire, Reston - Virginia

[43] Wright K.\&.R, Valencia Zegarra A., McEvan, F. (2011) Moray: Inca Engineering Mystery. Reston, Virginia: ASCE Press

[44] Zuma-Netshiukhwi,G., Stigter, K., Walker, S. (2013): "Use of Traditional Weather/Climate Knowledge by Farmers in the South-Western Free State of South Africa: Agrometeorological Learning by Scientists" Atmosphere 2013, 4, pp.383-410. 